\title{
Compatibility of indigenous isolates HR1, HR2 of entomopathogenic nematodes, with low-toxicity insecticides for control of fall armyworm, Spodoptera frugiperda (J.E. Smith) (Lepidoptera: Noctuidae) and tomato leafminer, Tuta absoluta (Meyrick) (Lepidoptera: Gelechiidae)
}

Indra Kumar Kasi ( $\nabla$ entomologist2018@gmail.com )

Dr Yashwant Singh Parmar University of Horticulture and Forestry https://orcid.org/0000-0001-8087-7934

Mohinder Singh

Dr Yashwant Singh Parmar University of Horticulture and Forestry

Kanchhi Maya Waiba

Banaras Hindu University Institute of Agricultural Sciences

\section{Research Article}

Keywords: Entomopathogenic nematode, Spinosad, Chlorantraniliprole, H. bacteriophora, S, feltiae, Spodoptera frugiperda, Tuta absoluta, synergistic effect

Posted Date: January 10th, 2022

DOl: https://doi.org/10.21203/rs.3.rs-1199047/v1

License: (c) (i) This work is licensed under a Creative Commons Attribution 4.0 International License. Read Full License 


\section{Abstract}

Invasive species are a major danger to agronomic and natural ecosystems, and due to environmental concerns about pesticide use, EPNs have the potential to replace larvicidal action in pest management. The goal was to see how well local isolates of Steinernema feltiae (HR1) and Heterorhabditis bacteriophora (HR2) controlled invasive species when combined with low-toxicity pesticides. HR1 + Spinosad, chlorantraniliprole produced over $90 \%$ mortality in larvae at 96 hours, while HR2 + Spinosad, chlorantraniliprole caused over 95\% mortality at 96 hours. After treatment, the high dose was regarded the least hazardous technique for controlling fall armyworm. At the high dose, HR1 + Spinosad, chlorantraniliprole produced larvae death of over 100 percent at 96 hours, and HR2 + Spinosad, chlorantraniliprole caused mortality of over 97.50 percent at 96 hours, and should be considered as a least hazardous strategy for T. absoluta management. Controlling larvae mortality of above $100 \%$ at 96 hours in combination with low-toxicity insecticide dosages should be included as a least harmful technique to control T. absoluta. The results showed that these HR2 strains have high pathogenicity against T. absoluta and $S$. frugiperda and have potential for control in integrated approaches, causing 100 percent and 90.00 percent mortality of T. absoluta and S. frugiperda at 96 hours at the high dose as a least toxic strategy to control.

\section{Highlights}

- Insecticide's compatibility of Steinernema feltiae and Heterorhabditis bacteriophora against Spodoptera frugiperda, and Tuta absoluta in tomato, maize was evaluated.

- Final instar larvae of $S$. frugiperda, were more susceptible than larvae of $T$. absoluta to the EPN isolates.

- Compatibility of indigenous isolates of entomopathogenic nematodes, with low-toxicity insecticides for control invasive species.

- EPN isolate HR1-HR2 has been found as a potential candidate for inclusion in IPM of S. frugiperda, and T. absoluta.

\section{Introduction}

The biological control system creates an environment that is more tolerant of chemical control methods. When used properly, it can do a lot of good, last a long time, and kill a lot of insects. According to the instructions, entomopathogenic nematodes (EPNs) suppress these species: Coleoptera, Diptera, Hemiptera, Hymenoptera, Orthoptera, Lepidoptera, Siphonaptera, Thysanoptera, and Isoptera. In weed control, these pests interact with natural pesticides (Khan et al. 2016; Kasi et al., 2021). Maize (Zea mays L.) is one of the world's most important grain crops, and after rice and wheat, India's third most important agricultural crop (Joshi et al. 2005). Pests and illnesses have caused a total loss of 13.20 percent of the crop in India, causing maize production to be disrupted (Kumar et al. 2014). Spodoptera frugiperda (JE Smith, 1797) (Family: Noctuidae) is an American lepidopteran bug that lives in the fall (Todd and Poole 1980). It's a wound infected with over 350 plant species that's wreaking havoc on the world's most vital crops, including maize, rice, sorghum, sugar, cotton, and other vegetable crops (CABI 2020). Following that, FAW was claimed to have attacked Central and Western Africa in 2016 (Goergen et al. 2016), the Indian subcontinent in Asia in 2018 (Sharanabasappa et al. 2018), and the distribution of land in Africa today (Goergen et al. 2018). (CABI 2020). FAW was reported erroneously in maize fields in Shivamogga, Karnataka, in May 2018 (Sharanabasappa et al. 2018) in the following scientific studies from various parts of India (Repalle et al. 2020).

The most essential approach of FAW control is the use of chemical insecticides (Belay et al. 2012). However, this pest has been found to develop resistance to a wide range of commonly used pesticides (Zhu et al. 2015) as well as the chemical proteins of Bacillus thuringiensis Berlin (Bacillaceae) (Murua et al. 2019); as a result, safe, clean, and easy-to-manage control strategies are required and being developed. Biological control is a promising technique against a variety of pests, and ecologically friendly biopesticides are more effective than pesticides. Entomopathogenic nematodes (EPNs), like other biological control agents, are potential and promising pest control agents (Lacey and Georgis 2012; Bhairavi et al., 2021). 
The Steinernematidae and Heterorhabditidae families of EPNs are natural insecticides (Abbas et al., 2021). Many researchers have indicated that EPN natural species are better at adapting to current environmental conditions than traditional problems (Bedding, 1990). Other employees did a study on the availability of $S$. frugiperda and other insect pests in EPNs (Viteri et al. 2018; Kasi et al., 2021).

Tomatoes (Solanum lycopersicum L.) are a South and Central American annual vegetable of the Solanaceae family. It rose to popularity as a result of its high food prices and consumption in the food sector (Canpolat, 2016; Golukcu et al. 2016). In India, tomatoes are the most productive vegetable on the planet. It is critical to safeguard its crops from diseases and pests because of their economic value. In locations where the climate is conducive to insects, red spider larvae, thrips, whiteflies, aphids, and leaf flies cause plant harm (Butut and Gocmen, 2000; Guncan et al. 2006). Invasive species pose a serious threat to the environment and agriculture. Tuta absoluta (Meyrick, 1917) (Lepidoptera: Gelechiidae), the tomato leafminer (TLM), is an invasive bug that has spread to many regions of the world in recent years, including India. T. absoluta larvae can penetrate and feed on all aerial parts of the host plant, including stems, leaves, shoots, and fruits (Desneux et al., 2010). Chemical management has been a prominent approach for pest control from its origins as an economic pest (Lietti et al., 2005). T. absoluta was first discovered in India in October 2014 in the mid-western state of Maharashtra (Sridhar et al., 2014). Tomato pinworm / small leaf, T. Absoluta, an invasive new invasive insect, was first discovered in Pune in 2014 in a tomato plant that grew in a field and a thousand houses, and in southwestern India (Karnataka state) (ICAR 2015). To our knowledge, there have been no reports of this pest in eastern, northern, and eastern India. The insect was then discovered on a farmer's field in major tomato-growing districts across the country, including Himachal Pradesh (Sharma and Gavkare, 2017). In response to carbon dioxide, insect movement, and insect faces, entomopathogenic nematodes (EPNs) are typically discovered in the surrounding soil (Kaya and Gaugler, 1993). Biopesticides from two families (Heterorhabditidae and Steinernematidae) have been utilised successfully in IPM programmes (Grewal et al. 2005; Alforja et al. 2021). The infective juvenile stage (IJ) is the last stage of EPNs' free life. 2 families afflicted with Photorhabdus and Xenorhabdus viruses, which kill their target insects with septicemia within 24-48 hours (Ferreira and Malan, 2014; Kasi et al., 2021).

More than 100 EPN species have been identified worldwide (about $80 \%$ are steinernematid), with at least 13 of them being marketed (Shapiro-llan et al. 2014). Inherent pathogenicity against various pest species varies widely among EPN species. Furthermore, the field efficacy of EPNs can be determined by differences in host-seeking strategy and tolerance to environmental circumstances such as temperature and desiccation across EPN species (Martens et al. 2004). EPNs have been widely used in the biological control of a wide range of economically relevant pests in a variety of settings (Grewal et al. 2005). However, the use of adjuvants to increase leaf coverage and persistence of the IJs, or the formulation of EPNs to retard desiccation, has increased the usage of EPNs against foliar pests (Williams and Watters 2000; Arthurs et al. 2002; Head et al. 2004).

\section{Materials \& Methods}

\section{Insects}

Under greenhouse circumstances, a T. absoluta colony was maintained on tomato plants. The colony was started with larvae collected in September 2020 from the vegetable science departmental form tomato greenhouse at Dr. Yashwant Singh Parmar University of Horticulture and Forestry, Solan, HP, India, which used local strains of S. feltiae (HR1) and $H$. bacteriophora (HR2) indigenous strains (Poinar) for pest control.

\section{Entomopathogenic nematodes}

In this investigation, two isolates of $S$. feltiae and $H$. bacteriophora were employed. They were utilised without culturing in the tests. G. mellonella larvae were used as nematode traps to extract the native isolate from soil samples collected in Rajgarh, Himachal Pradesh, India. This strain was cultivated on G. mellonella last instar larvae at $211^{\circ} \mathrm{C}$ using the 
technique (Kaya and Gaugler 1993). Infectious juveniles (IJs) were collected from white traps maintained at $4^{\circ} \mathrm{C}$ in distilled water for up to 14 days once they emerged during the first ten days. Before being employed in the tests, the nematodes were acclimatised at room temperature for around 30 minutes.

\section{Insect source}

Larvae were taken from cornfields in the Department of Vegetable Science, Dr. YSPUHF, Nauni, Himachal Pradesh, India, to start the first $S$. frugiperda colony. The young corn plant feed was then placed in test tubes measuring $15 \mathrm{~cm}$ in height and $1.5 \mathrm{~cm}$ in diameter. They were sexed and transported to PVC tubes $10 \mathrm{~cm}$ in diameter and $20 \mathrm{~cm}$ in height after transforming into pupae, with the tube extremities closed with a voile-type fabric and sealed with elastic. The tubes were lined with filter paper on the inside so that the females could oviposit shortly after the adults emerged. The moths were fed $10 \%$ honey isolates placed in a tube with cotton on a daily basis. The newly hatched caterpillars were placed in test tubes with the same artificial diet after being sterilised Petri dishes with an artificial diet were obtained.

TLM larvae and pupae were obtained from a greenhouse that had been invaded. T. absoluta was grown in a greenhouse at a temperature of $26^{\circ} \mathrm{C}$, a relative humidity of $60 \%$, and a photoperiod of L:D 8:16. The insects were raised on tomato plants in hardwood framed cages with 80 mesh organdy linen (S. lycopersicum L.). In the oviposition cage, the adults were fed a $10 \%$ sugar solution.

\section{Methodology:}

In a $20 \mathrm{~mL}$ plastic cup with a tiny amount of maize feed, one caterpillar was inserted (natural feed). Two biological agents, three insecticides, and an organic agent with low-toxic pesticides have their low- and high-dose labels (translated into lab dosage) registered (Table 1). A total of fifteen larvae were given a topically applied pesticide solution of 200 litres each dose. Only distilled water was used for the control. The caught cups were housed in the lab at 18 to $20^{\circ} \mathrm{C}$ with a recording duration of $12: 12 \mathrm{~h}$ in a randomly controlled 4-block construction (total $\mathrm{n}=40$ larvae per dosage) (L: D). Between 24- and 96-hours following application, mortality was measured. In different assays, the insecticide diagnosis of $1 / 4 \mathrm{X}, 1 / 2 \mathrm{X}, \mathrm{X}, 1 / 2 \mathrm{y}$, and $y$ insecticide was applied to 60 larvae per treatment to calculate the lethal doses (LD50) of chlorantraniliprole and Spinosad at 96 hours $(x=$ dose low and $y=$ maximum value is equal to the size registered and described in (Table 1) (Viteri et al., 2018). 
Table 1

To suppress fall armyworm and tomato leafminer larvae, researchers tested the efficiency of two biological agents, three synthetic insecticides, and the least toxic insecticide combinations.

\begin{tabular}{|c|c|c|c|c|c|}
\hline \multirow[t]{2}{*}{ Insecticides } & \multirow{2}{*}{$\begin{array}{l}\text { Commercial name* } \\
\text { Active ingredient and } \\
\text { percentage }\end{array}$} & \multicolumn{2}{|l|}{ Low dosage } & \multicolumn{2}{|l|}{ High dosage } \\
\hline & & $\mathrm{g}$ or $\mathrm{mL}$ per $\mathrm{L}$ & PPM & $\mathrm{g}$ or $\mathrm{mL}$ per $\mathrm{L}$ & PPM \\
\hline \multicolumn{6}{|l|}{ Bio agent (nematode) } \\
\hline $\begin{array}{l}\text { Steinernema feltiae }(\mathrm{Sf})+\text { rape } \\
\text { seed oil } 85 \%\end{array}$ & Local strain + Addit & $1.1 \mathrm{~g}+2.5 \mathrm{ml}$ & $\begin{array}{l}1134+ \\
2500\end{array}$ & $2.2 \mathrm{~g}+2.5 \mathrm{ml}$ & $\begin{array}{l}2268 \\
+ \\
2500\end{array}$ \\
\hline $\begin{array}{l}\text { H. bacteriophora }(\mathrm{Hb})+\text { rape seed } \\
\text { oil } 85 \%\end{array}$ & Local strain + Addit & $1.1 \mathrm{~g}+2.5 \mathrm{ml}$ & $\begin{array}{l}1134+ \\
2500\end{array}$ & $2.2 \mathrm{~g}+2.5 \mathrm{ml}$ & $\begin{array}{l}2268 \\
+ \\
2500\end{array}$ \\
\hline \multicolumn{6}{|l|}{ Insecticides } \\
\hline Chlorantraniliprole 18.4\% & Coragen $®$ & $0.8 \mathrm{ml}$ & 800 & $0.16 \mathrm{ml}$ & 1600 \\
\hline Indoxacarb $14.5 \%$ & Syngenta & $0.12 \mathrm{ml}$ & 120 & $0.24 \mathrm{ml}$ & 240 \\
\hline Spinosad $2.5 \%$ & MH Dow Success ${ }^{\circledR}$ & $0.2 \mathrm{ml}$ & 200 & $0.4 \mathrm{ml}$ & 400 \\
\hline \multicolumn{6}{|l|}{ Combinations } \\
\hline Chlorantraniliprole + SF + oil & - & $0.8+1.1+2.5$ & - & $0.16+2.2+2.5$ & - \\
\hline Indoxacarb + SF + oil & - & $0.12+1.1+2.5$ & - & $0.24+2.2+2.5$ & - \\
\hline Spinosad + SF + oil & - & $0.2+1.1+2.5$ & - & $0.4+2.2+2.5$ & - \\
\hline
\end{tabular}

Ten larvae were placed in an $8 \mathrm{~cm}$ petri dish with the natural diet of tomato leaves. Two biological agents, three synthetic insecticides, and the biological agent + low-toxicity insecticides were employed at low and high registered label dosages (converted to lab dosages) (Table 1). Each dosage consisted of ten larvae given topically with 200 I of pesticide solution. Only distilled water was used as a control. In the lab, treated Petri dishes were kept in a CRD design with four replications (total $\mathrm{n}=40$ larvae per dosage) at 18 to $20^{\circ} \mathrm{C}$ and photoperiod $12: 12 \mathrm{~h}$ in a CRD design with four replications (total $\mathrm{n}=40$ larvae per dosage) (L:D). The mortality of larvae was measured between 24- and 96-hours following application.

\section{Statistical analysis}

The data was corrected for control larval mortality in the bioassays using Abbott's formula (Fleming and Retnakarn 1985), and PROBIT analysis was performed. LSD (P 0.05) values were also calculated to distinguish means between treatments.

\section{Results}

\section{Bioassays with S. feltiae + S. frugiperda + Insecticides}

High values $(F=61.77 ; d f=12 ; P 0.05)$ were associated with the highest percentage mortality rate (Table 2$)$. S. feltiae and Spinosad, on the other hand, produced 80 to 97 percent worm death in 96 hours at low and high rates. At the greatest rate, chlorantraniliprole and Spinosad consumption resulted in a mortality rate of up to 97.50 percent in 96 hours. These results differ from those reported by Belay et al. (2012), who found that Spinosad and chlorantraniliprole cause more than $80 \%$ of worm fatalities at the same time. In this investigation, the LD50 for chlorantraniliprole was 1600 ppm and for Spinosad was 400 ppm for 96 hours. The differences could be due to (1) long-term use of these active chemicals, resulting in a 
specific level of resistance, (2) the study's stage, third or fifth stage, or (3) variances between island larvae (Viteri et al., 2018). Indoxacarb, on the other hand, killed 75 and 90 percent of worms at low and high rates, respectively, after 96 hours.

Table 2

Percentage of mortality of fifth-instar fall armyworm [Spodoptera frugiperda (J.E. Smith) (Lepidoptera: Noctuidae)] larvae at low and high doses of three insecticides, as well as the least toxic combinations, from 24 to 96 hours.

\begin{tabular}{|c|c|c|c|c|c|c|c|c|c|}
\hline & $24 \mathrm{~h}$ & & $48 \mathrm{~h}$ & & $72 \mathrm{~h}$ & & $96 \mathrm{~h}$ & & \\
\hline Insecticides & Low & High & Low & High & Low & High & Low & High & Interaction* \\
\hline \multicolumn{10}{|l|}{ Bio agent (nematode) } \\
\hline $\begin{array}{l}\text { Steinernema feltiae } \\
\text { (Sf) }\end{array}$ & 15.00 & 22.50 & 27.50 & 40.00 & 40.00 & 52.50 & 52.50 & 60.00 & $(+)$ \\
\hline \multicolumn{10}{|l|}{$\begin{array}{l}\text { Toxicity } \\
\text { insecticides }\end{array}$} \\
\hline Chlorantraniliprole & 4.50 & 7.50 & 6.50 & 12.50 & 8.50 & 12.50 & 18.50 & 25.00 & $(-)$ \\
\hline Indoxacarb & 0.00 & 0.00 & 4.50 & 7.50 & 9.00 & 15.00 & 15.50 & 22.50 & $(-)$ \\
\hline Spinosad & 4.00 & 10.00 & 8.50 & 15.00 & 12.50 & 20.00 & 17.50 & 27.50 & $(-)$ \\
\hline \multicolumn{10}{|l|}{ Combinations } \\
\hline $\begin{array}{l}\text { Chlorantraniliprole } \\
+\mathrm{Sf}\end{array}$ & 20.00 & 27.50 & 35.00 & 40.00 & 45.00 & 50.00 & 62.50 & 87.50 & Synergistic \\
\hline Indoxacarb + Sf & 17.50 & 22.50 & 27.50 & 32.50 & 37.50 & 47.50 & 60.00 & 82.50 & Synergistic \\
\hline Spinosad + Sf & 25.00 & 30.00 & 35.00 & 42.50 & 42.50 & 57.50 & 65.00 & 90.00 & Synergistic \\
\hline Mean & 12.28 & 17.14 & 20.64 & 27.14 & 27.85 & 36.42 & 41.64 & 56.42 & \\
\hline LSD $(p<0.05)$ & 4.15 & 5.96 & 5.23 & 6.91 & 4.96 & 6.14 & 6.15 & 7.37 & \\
\hline
\end{tabular}

When S. feltiae was coupled with Spinosad and chlorantraniliprole, the percentage of mortality was higher by 24 hours than when these pesticides were applied alone, regardless of the dose employed (Table 2). Furthermore, at 72 hours, a very significant proportion of worm mortality (over 90\%) was identified in high doses. Similarly, when larvae were exposed to two different modes of action [septicemia ( $S$. feltiae) + lysed midgut epithelial cell (Spinosad), paralysed muscle (chlorantraniliprole), or Indoxacarb neural transmission (spinetoram)] at the same time (Viteri et al., 2018), the combination was active (90.00 percent of dead larvae) at a higher dose at Armyworm colonies from Florida emerge in the fall (Viteri et al., 2018). More research is needed, however, to strengthen this collaborative effect.

\section{Bioassays with $\mathrm{H}$. bacteriophora + S. frugiperda + Insecticides}

High rates were associated with the highest percentage mortality rate $(F=67.09 ; \mathrm{df}=12 ; \mathrm{P0} 0.05)$ (Table 3$)$. At low and high 96-hour rates, however, $H$. bacteriophora and Spinosad killed 72.50 to 95 percent of the larvae. At the greatest rate, chlorantraniliprole and Spinosad consumption resulted in a mortality rate of up to 92.50 percent in 96 hours. These effects differ from those previously described, in which Spinosad and chlorantraniliprole together killed more than 95 percent of foxes. In this investigation, the LD50 for Spinosad was 400 ppm and for chlorantraniliprole was 1600 ppm for 96 hours. The discrepancy could be due to (1) long-term usage of these active components, resulting in a certain level of resistance, (2) the study's stage, third or fifth stage, or (3) variances in the island population. Indoxacarb, on the other hand, induced a 65 and 87.50 percent worm mortality rate at lower and higher dosages, respectively, at 96 hours. 
Table 3

Percentage of mortality of fifth-instar fall armyworm [Spodoptera frugiperda (J.E. Smith) (Lepidoptera: Noctuidae)] larvae at low and high doses of three insecticides, as well as the least toxic combinations among them, assessed from 24 to 96 hours.

\begin{tabular}{|c|c|c|c|c|c|c|c|c|c|}
\hline & $24 \mathrm{~h}$ & & $48 \mathrm{~h}$ & & $72 \mathrm{~h}$ & & $96 \mathrm{~h}$ & & \\
\hline Insecticides & Low & High & Low & High & Low & High & Low & High & Interaction* \\
\hline \multicolumn{10}{|c|}{ Bio agent (nematode) } \\
\hline $\begin{array}{l}\text { H. bacteriophora } \\
(\mathrm{Hb})\end{array}$ & 35.00 & 45.00 & 45.00 & 55.00 & 50.00 & 60.00 & 55.00 & 65.00 & $(+)$ \\
\hline \multicolumn{10}{|l|}{$\begin{array}{l}\text { Toxicity } \\
\text { insecticides }\end{array}$} \\
\hline Chlorantraniliprole & 7.50 & 12.50 & 10.50 & 17.50 & 18.50 & 22.50 & 20.00 & 27.50 & $(-)$ \\
\hline Indoxacarb & 6.50 & 10.00 & 8.00 & 15.00 & 13.00 & 17.50 & 16.50 & 22.50 & $(-)$ \\
\hline Spinosad & 8.50 & 15.00 & 12.00 & 20.00 & 19.50 & 25.00 & 21.50 & 30.00 & $(-)$ \\
\hline \multicolumn{10}{|l|}{ Combinations } \\
\hline $\begin{array}{l}\text { Chlorantraniliprole } \\
+\mathrm{Hb}\end{array}$ & 45.00 & 75.00 & 57.50 & 87.50 & 62.50 & 87.50 & 67.50 & 92.50 & Synergistic \\
\hline Indoxacarb + Hb & 50.00 & 72.50 & 55.00 & 77.50 & 60.00 & 82.50 & 65.00 & 87.50 & Synergistic \\
\hline Spinosad $+\mathrm{Hb}$ & 57.50 & 77.50 & 62.50 & 85.00 & 67.50 & 90.00 & 72.50 & 95.00 & Synergistic \\
\hline \multirow[t]{2}{*}{ Mean } & 30.00 & 43.92 & 35.78 & 51.07 & 41.57 & 55.00 & 45.42 & 60.00 & \\
\hline & 4.23 & 5.55 & 7.12 & 8.06 & 8.15 & 9.81 & 6.16 & 7.79 & \\
\hline
\end{tabular}

In comparison to the use of these insecticides alone, $H$. bacteriophora in combination with Spinosad and chlorantraniliprole resulted in a higher percentage of mortality by 24 hours, regardless of the dose utilised (Table 3 ). Furthermore, high doses resulted in a very high percentage of worm deaths (almost 90\%) at 72 hours. Similarly, the combination of $\mathrm{Hb}+\mathrm{Spinosad}$ was active ( 95.00 percent of dead larvae) with a high dose of 96 hours, compared to very low mortality caused by Spinosad (21.50 percent), or $\mathrm{Hb}$ (55.00 percent) was used alone, the larvae were used alone to develop the following methods -2 variety of action [septicemia (H. bacteriophora) + lysed midgut epithelial cell $(\mathrm{Hb})$, muscle spasm (At the time of the army's defeat. More research is needed, however, to strengthen this collaborative effect.

\section{Bioassays with S. feltiae + T. absoluta + Insecticides}

In general, greater dosages resulted in a higher mean percent mortality ( $F=52.99 ; \mathrm{df}=12 ; \mathrm{P} 0.05)$. (Table 4). Low and high dosages of $S$. feltiae and Spinosad, on the other hand, induced 80 to 97 percent larvae mortality at 96 hours. At the higher dosage, the usage of chlorantraniliprole and Spinosad resulted in mortality rates of up to 97.50 percent at 96 hours. These findings differ from those reported by Belay et al. (2012), who found that Spinosad and chlorantraniliprole caused over $80 \%$ larvae mortality within the same time period. In this investigation, the LD50 for chlorantraniliprole was 1600 ppm and for Spinosad was 400 ppm after 96 hours. Variances could be due to (1) the active components' long-term use causing resistance, (2) the instar stage employed in this study (third vs. fifth), or (3) differences across fall armyworm populations on the island (Viteri et al. 2018). Indoxacarb, on the other hand, caused 72.50 and 90 percent mortality in larvae at 96 hours in low and high dosages, respectively. 
Table 4

Mortality of tomato pinworm [Tuta absoluta M.] larvae in the last instar at low and high doses of three insecticides, as well as the least lethal combinations among them, was measured from 24 to 96 hours.

\begin{tabular}{|c|c|c|c|c|c|c|c|c|c|}
\hline & $24 \mathrm{~h}$ & & $48 h$ & & $72 \mathrm{~h}$ & & $96 \mathrm{~h}$ & & \\
\hline Insecticides & Low & High & Low & High & Low & High & Low & High & Interaction* \\
\hline \multicolumn{10}{|l|}{$\begin{array}{l}\text { Bio agent } \\
\text { (nematode) }\end{array}$} \\
\hline $\begin{array}{l}\text { Steinernema feltiae } \\
\text { (Sf) }\end{array}$ & 10.00 & 15.00 & 30.00 & 32.50 & 45.00 & 55.00 & 57.50 & 67.50 & $(+)$ \\
\hline \multicolumn{10}{|l|}{$\begin{array}{l}\text { Toxicity } \\
\text { insecticides }\end{array}$} \\
\hline Chlorantraniliprole & 9.50 & 12.50 & 10.00 & 17.50 & 20.50 & 30.00 & 45.50 & 62.50 & $(-)$ \\
\hline Indoxacarb & 4.50 & 7.50 & 8.50 & 12.50 & 19.50 & 25.00 & 29.50 & 67.50 & $(-)$ \\
\hline Spinosad & 5.00 & 10.00 & 9.00 & 15.00 & 20.50 & 27.50 & 42.50 & 70.00 & $(-)$ \\
\hline \multicolumn{10}{|l|}{ Combinations } \\
\hline $\begin{array}{l}\text { Chlorantraniliprole+ } \\
\text { Sf }\end{array}$ & 22.50 & 27.50 & 40.00 & 42.50 & 52.50 & 57.50 & 75.00 & 97.50 & Synergistic \\
\hline Indoxacarb + Sf & 20.00 & 30.00 & 30.00 & 37.50 & 40.00 & 57.50 & 72.50 & 90.00 & Synergistic \\
\hline Spinosad + Sf & 25.00 & 27.50 & 37.50 & 45.00 & 52.50 & 70.00 & 80.00 & 97.50 & Synergistic \\
\hline Mean & 13.78 & 18.57 & 23.57 & 28.92 & 35.78 & 46.07 & 57.50 & 78.92 & \\
\hline LSD $(p<0.05)$ & 4.82 & 5.21 & 5.12 & 5.83 & 4.90 & 5.47 & 7.15 & 8.28 & \\
\hline
\end{tabular}

In comparison to the use of these insecticides alone, S. feltiae in combination with Spinosad and chlorantraniliprole resulted in higher percentages of mortality at 24 hours, regardless of the dosage utilised (Table 4). Furthermore, high doses at 72 hours resulted in the highest percentages of larval mortality (above 95\%). Similarly, when compared to the lowest mortality produced by Spinosad (20.50 percent) or S. feltiae (45.00 percent) applied alone, the combination of Spinosad + S. feltiae was successful (70.00 percent of dead larvae) at the maximum dose at 96 hours (Viteri et al. 2018). Septicemia (S. feltiae) + lysed midgut epithelial cells (Spinosad), disturbed muscle regulation (chlorantraniliprole), or Indoxacarb neural transmission (spinetoram) exposed larvae to two separate modes of action at the same time (Viteri et al. 2018). Armyworm numbers from Florida peak in the fall (Yu 1991). However, more research is needed to confirm that this synergistic impact exists.

\section{Bioassays with H. bacteriophora + T. absoluta + Insecticides}

In general, higher doses resulted in a higher mean percent mortality $(F=72.98 ; \mathrm{df}=12 ; \mathrm{P} 0.05)$. (Table 5). With low and high dosages at 96 hours, H. bacteriophora with Spinosad induced 75.00 to 100\% larval mortality. At the higher dosage, the usage of chlorantraniliprole and Spinosad resulted in mortality rates of up to 97.50 percent at 96 hours. These findings differ from those reported by Belay et al. (2012), who found that Spinosad and chlorantraniliprole caused over 95 percent larvae death within the same time period. In this investigation, the LD50 for Spinosad was 400 ppm and for chlorantraniliprole was 1600 ppm after 96 hours. Variances could be due to (1) the active components' long-term use causing resistance, (2) the instar stage employed in this study (third vs. fifth), or (3) differences across fall armyworm populations on the island (Viteri et al. 2018). Indoxacarb, on the other hand, caused 67.50 and 95.00 percent mortality in larvae after 96 hours at low and high doses, respectively. 
Table 5

Mortality of tomato pinworm [Tuta absoluta M.] larvae in the fifth instar at low and high doses of three insecticides, as well as the least lethal combinations among them, was measured from 24 to 96 hours.

\begin{tabular}{|c|c|c|c|c|c|c|c|c|c|}
\hline \multirow[b]{2}{*}{ Insecticides } & \multicolumn{2}{|l|}{$24 \mathrm{~h}$} & \multicolumn{2}{|l|}{$48 \mathrm{~h}$} & \multicolumn{2}{|c|}{$72 \mathrm{~h}$} & \multicolumn{2}{|c|}{$96 \mathrm{~h}$} & \multirow[b]{2}{*}{ Interaction* } \\
\hline & Low & High & Low & High & Low & High & Low & High & \\
\hline \multicolumn{10}{|l|}{$\begin{array}{l}\text { Bio agent } \\
\text { (nematode) }\end{array}$} \\
\hline $\begin{array}{l}\text { H. bacteriophora } \\
(\mathrm{Hb})\end{array}$ & 22.50 & 27.50 & 45.00 & 47.50 & 57.50 & 62.50 & 65.00 & 70.00 & $(+)$ \\
\hline \multicolumn{10}{|l|}{$\begin{array}{l}\text { Toxicity } \\
\text { insecticides }\end{array}$} \\
\hline Chlorantraniliprole & 22.50 & 35.00 & 31.50 & 47.50 & 41.50 & 55.00 & 49.50 & 60.00 & $(-)$ \\
\hline Indoxacarb & 17.50 & 32.50 & 25.50 & 47.50 & 43.50 & 60.00 & 47.50 & 62.50 & $(-)$ \\
\hline Spinosad & 20.00 & 40.00 & 28.50 & 55.00 & 35.50 & 62.50 & 40.50 & 65.00 & $(-)$ \\
\hline \multicolumn{10}{|l|}{ Combinations } \\
\hline $\begin{array}{l}\text { Chlorantraniliprole } \\
+\mathrm{Hb}\end{array}$ & 47.50 & 62.50 & 57.50 & 77.50 & 65.00 & 87.50 & 70.00 & 97.50 & Synergistic \\
\hline Indoxacarb $+\mathrm{Hb}$ & 45.00 & 60.00 & 57.50 & 75.00 & 62.50 & 85.00 & 67.50 & 95.00 & Synergistic \\
\hline Spinosad + Hb & 52.50 & 65.00 & 65.00 & 90.00 & 70.00 & 95.00 & 75.00 & 100.0 & Synergistic \\
\hline Mean & 32.50 & 46.07 & 44.35 & 62.85 & 53.64 & 72.50 & 59.28 & 78.57 & \\
\hline $\operatorname{LSD}(p<0.05)$ & 5.12 & 6.31 & 7.15 & 8.05 & 5.29 & 6.59 & 6.20 & 7.40 & \\
\hline
\end{tabular}

In comparison to the use of these insecticides alone, $H$. bacteriophora in combination with Spinosad and chlorantraniliprole resulted in higher percentages of mortality at 24 hours, regardless of the dosage utilised (Table 5). Furthermore, high doses at 72 hours resulted in the highest percentages of larval mortality (above 95.00 percent). Similarly, when compared to the lowest mortality produced by Spinosad (40.50 percent) or $\mathrm{Hb}$ (65.00 percent) applied alone, the combination of $\mathrm{Hb}+$ Spinosad was effective (100 percent of dead larvae) with the high dose at 96 hours (Viteri et al. 2018). Septicemia ( $H$. bacteriophora) + lysed midgut epithelial cells $(\mathrm{Hb})$, poor muscle control (Spinosad), or aberrant neural transmission (spinetoram) in larvae exposed to two separate modes of action at the same time, (Viteri et al. 2018) caused their greater mortality. Armyworm populations peak in the fall (Yu 1991). However, more research is needed to confirm that this synergistic impact exists.

\section{Discussion}

The study involved evaluation on the susceptibility of $S$. frugiperda and T. absoluta to 2 species of EPNs isolated from Himachal Pradesh, North-Western India. Extra exposure duration is linked to higher mortality because it allows for more time for insect infection via IJs (Ebssa and Koppenhofer 2012). (Razia and Sivaramakrishnan, 2016) found a link between testing and exposure time, as well as mortality and variations between nematode and termite species from the LT and LD. The rate of acceptance raised the death rate as well (El-Bassiouny and El-Rahman 2011). Diverse EPN kinds of Heterorhabditis and Steinernema have exhibited different responses to different types of pests in a series of laboratory bioassays throughout the years (Abbas, 2021; Kasi et al., 2021). It could be because of the type of environmental factors that are extensively utilised by the nature of parasitic bacteria interactions (Xenorhabdus spp. And Photorhabdus spp. In the case of Heterorhabditis spp. 2010). The death data obtained during the current study is similar to the death data obtained during the previous investigation (Devi et al., 2018; Han et al., 2019) 
The amount of the fall armyworm larva differed between different species of nematodes, which is not unusual. (Andalo et al., 2010; Viteri et al., 2018) found that when Heterorhabditis sp. and S. arenarium were used to treat 200 IJs/ 5th instant dosage $S$. frugiperda, the mortality rates were 96.07 and 100.00 percent, respectively. H. Indica and S. surkhetense caused 75.00 percent of mortality 48 hours after incubation, while (Nouh, 2021; Alforja et al., 2021) found that the concentrations of 50 and $100 \mathrm{IJs}$ in S. Diarrhea caused 93.00 and 100.00 percent of deaths, respectively. The current study found that $H$. indica causes 68.78 percent death in $50 \mathrm{IJs} / 5$ th instar worms after 120 hours of incubation, while S. Sangi, H. baujardi, and S. surkhetense cause 75.00 percent mortality. Both S. sangi and S. surkhetense produced 81.25 percent mortality in 100 IJs / 5th instar larvae. Garcia et al. (2008; Nouh, 2021; Abbas et al., 2021) revealed that against 3rd instar larvae of $S$. frugiperda, Steinernema sp. (280 IJs / worm) and H. Indica caused 100.00 percent death; S. surkhetense and H. Baujardi caused 93.75 and 87.50 percent death, respectively. Variations in nematode species and the life cycle of this insect could explain the modest variance in mortality rates and other research. $H$. Indica appears to be much more effective in terms of LC50 and LT50, as well as host penetration and cadaver reproduction, according to preliminary research (Kasi et al., 2021; Bhairavi et al., 2021). It has showed an increase in sickness among isolated EPNs, indicating that current climatic circumstances are highly variable.

One of the most essential variables in the development of EPNs is host penetration (Kaya and Gaugler, 1993). Differences in the hostel's intensity in the fight against pests can be linked to its ability to attack and penetrate EPN species (Glazer et al. 2001; Nouh, 2021; Bhairavi et al., 2021). According to data from various scientific examinations, the levels of EPN detainee attacks were categorised into broad-spectrum and narrow-spectrum (Phan et al. 2005; Waiba et al., 2021; Kasi et al., 2021). Large levels of infestation may be accompanied by high amounts of toxic production (Akhurst and Boemare, 1990; Viteri et al., 2018), resulting in the insect's extinction. Since some workers are still working, the determination of violence has changed with the species of animals. They have documented a lack of correlation between entry and mortality rates (Ricci et al. 1996; Alforja et al., 2021). Existing investigations have revealed that EPN strains can be effectively infected and regenerated, revealing their potential as powerful biopesticides. (Caccia et al., 2014; Abbas et al., 2021) investigated the capacity of $S$. diaprepesium in $S$. frugiperda, finding that the nematode pro produced 11,329 and 27,155 IJs, respectively, in concentrations of IJs/100. The results of a study into the creation of EPN isolates revealed considerable differences between the four types, which are compatible with the findings of (Rahoo et al., 2018; Alforja et al., 2021), who found that the fertility rate varies greatly between EPN variants. A high rate of recurrence in the pupal phase as a discovered test, on the other hand, could be linked to the keeper's weight and content (Loya and Howe 2003; Kasi et al., 2021).

Other studies have shown that EPNs can detect and kill all four larvae inside or outside the leaf exhibition in T. absoluta final instar larvae; other research have shown that EPNs can detect and kill all four larvae inside or outside the leaf exhibition in T. absoluta final instar larvae (Batalla-Carrera et al., 2010; Van Damme et al., 2016). T. absoluta larvae were shown to be highly susceptible to EPNs (Batalla-Carrera et al., 2010; Abbas, 2021). As a result, they underline the importance of installing EPNs in the upper portion of the tomato plant to enable optimal pest management using the most appropriate separators against a specific pest in a given location. Local EPN dividers were able to kill T. absoluta and discovered that they were successful in killing white grubs in Rwanda (Kajuga et al., 2018; Kasi et al., 2021), despite the fact that finding EPNs capable of killing them was difficult (Kajuga et al., 2018; Kasi et al., 2021). (Laznik et al., 2015). Despite the fact that EPNs live in soil, various researchers have discovered that they can be used in the upper parts of the plant to effectively control insects such as litter leaf (Batalla-Carrera et al., 2010; Garcia-del- Pino et al., 2013), which is consistent with the findings of the current study. One of the most essential variables in the development of EPNs is host penetration (Kaya and Gaugler 1993; Nouh, 2021). It's possible that the hostel's ability to attack and pierce EPN species is due to insect sex differences (Glazer et al. 2001; Han et al., 2019). He also mentioned that, according to various findings from other scientific research, the levels of attacks on EPN convicts were categorised into broad groups (Phan et al. 2005). High import levels have been linked to harmful manufacturing (Akhurst and Boemare 1990; Abbas et al., 2021). This could be because a large number of EPNs will result in a large number of bacterial symbiotics being excreted in the keeper's body, 
increasing the rate of killing due to greater digestion of hazardous tissue and hydrolytic enzymes generated by these bacteria (Van Damme et al. 2016). The EPNs' visual performance and speed allow them to compete with popular insecticides chosen for their quick action, among other things (Macharia et al. 2009 and Biondi et al. 2018). Other features that make EPNs a viable candidate for IPM and roles that can replace pesticides include security, high violence, the ability to actively search their clients, the ability to produce in big amounts, and compliance with numerous pesticides (Lima et al. 2018; Bhairavi et al., 2021). As a result, more research is needed to determine its usefulness in real-world situations.

\section{Conclusions}

Our findings suggest that local indigenous strains HR1 and HR2 were acceptable hosts for lepidopteran, Spodoptera frugiperda, and Tuta absoluta. The nematode completed its life cycle and produced a large number of IJs, indicating that it has significant biological control potential in IPM. To control larvae in bioassays, in combination with low-toxicity pesticides at low and high dosages. HR1 + Spinosad, chlorantraniliprole, and HR2 + Spinosad or chlorantraniliprole caused larvae mortality of over $90 \%$ and $100 \%$ at 96 hours at the high dose, respectively, and should be considered as a least toxic control method.

\section{Declarations}

\section{Acknowledgements}

We would like to acknowledge the Dr. Yashwant Singh Parmar University of Horticulture and Forestry, Nauni, Solan, HP, India-173230 for support of this research. And Indian council of Agricultural Research (ICAR) for providing necessary facilities and financial support, respectively We are also grateful to Department of entomology, Nematology laboratory used in this study.

\section{Author contributions}

This study is part of a Ph.D. thesis, Indra Kumar Kasi designed the experiment. KI conducted the laboratory bioassays, performed data analysis and drafted the manuscript with inputs from all authors. MS, and MW collaborated closely with KI in the whole process especially during data analysis. All authors read and approved the final manuscript.

\section{Funding.}

No funding from any source.

\section{Declarations}

Conflict of interest The authors have no relevant financial or non-financial interests to disclose.

\section{References}

1. Abbas, W., Javed, N., Haq, I. U., \& Ahmed, S. (2021). Pathogenicity of entomopathogenic nematodes against cabbage butterfly (Pieris brassicae) Linnaeus (Lepidoptera: Pieridae) in laboratory conditions. Int J Trop Insect Sci, 41, 525-531. https://doi.org/10.1007/s42690-020-00236-2.

2. Abbott, W. S. (1925). A method of computing the effectiveness of an insecticide. J Econ Entomolo, 18, 265-267

3. Andalo, V., Santos, V., Moreira, G. F., Moreira, C. C., \& Moino, J. A. (2010). Evaluation of entomopathogenic nematodes under laboratory and greenhouses conditions for the control of Spodoptera frugiperda. Ciencia Rural, 40, 1860-1866. https://doi.org/10.1590/S0103-84782010005000151 
4. Arthurs, S., Heinz, K. M., \& Prasifka, J. R. (2004). An analysis of using entomopathogenic nematodes against aboveground pests. Bulletin of Entomological Research, 94, 297-306. https://doi.org/10.1079/BER2003309

5. Barati, R., Hejazi, M. J., \& Mohammadi, S. A. (2018). Insecticide susceptibility in Tuta absoluta (Lepidoptera: Gelechiidae) and metabolic characterization of resistance to diazinon. J Econ Entomol, 111, 1551-1557. https://doi.org/10.1093/jee/toy134

6. Batalla-Carrera, L., Morton, A., \& Garcia-del-Pino, F. (2010). Efficacy of entomopathogenic nematodes against tomato leafminer Tuta absoluta in laboratory and greenhouse conditions. Bio Control, I55, 523-530. https://doi.org/10.1007/s10526-010-9284-z

7. Belay, D. K., Huckaba, R. M., \& Foster, J. E. (2012). Susceptibility of the fall armyworm, Spodoptera frugiperda (Lepidoptera: Noctuidae), at Santa Isabel, Puerto Rico, to different insecticides. Flori Entomol, 95, 476-478. https://doi.org/10.1653/024.095.0232

8. Bird, A. F., \& Akhurst, R. J. (1983). The nature of the intestinal vesicle in nematodes of the family Steinernematidae. Int J of Parasit, 13, 599-606. https://doi.org/10.1016/S0020-7519(83)80032-0

9. Blanco, C. A., Portilla, M., Jurat, J. L., Sánchez, J. F., Viteri, D., Vega, P. ... Jackson, R. (2010). Susceptibility of is families of Spodoptera frugiperda (Lepidoptera: Noctuidae) to Cry1Ac and Cry1Fa proteins of Bacillus thuringiensis. Southwestern Entomologist, 35, 409-415. https://doi.org/10.3958/059.035.0325

10. CABI (2020). Invasive Species Compendium, Wallingford. https://www.cabi.org/isc. Accessed 26 Oct 2020

11. Carvalho, R. A., Omoto, C., Field, L. M., Williamson, M. S., \& Bass, C. (2013). Investigating the molecular mechanisms of organophosphate and pyrethroid resistance in the fall armyworm Spodoptera frugiperda.PLOS One8:1-11. https://doi.org/10.1371/journal.pone.0062268

12. Desneux, N., Wajnberg, E., Wyckhuys, K. A. G., Burgio, G., Arpaia, S., 'ez-Vasquez, N. ... Urbaneja, T. A (2010). Biological invasion of European tomato crops by Tuta absoluta: ecology, history of invasion and prospects for biological control. J Pest Sci, 83, 197-215. https://doi.org/10.1007/s10340-010-0321-6.

13. Doucet, M. M. A., Bertolotti, M. A., Giayetto, A. L., \& Miranda, M. A. (1999). Host range, specificity, and virulence of Steinernema feltiae, Steinernema rarum, and Heterorhabditis bacteriophora (Steinernematidae and Heterorhabditidae) from Argentina. J of Invert Patholo 73:237-242. https://doi.org/10.1006/jipa.1998.4831

14. Dowds, B. C. A., \& Peters, A. (2002). Virulence mechanisms.. In: In Gaugler, R. (Ed.), Entomopathogenic Nematology (pp. 79-98). New York, USA: CABI Publishing

15. Espky, N. D., \& Capinera, J. L. (1994). Invasion efficiency as a measure of efficacy of the entomogenous nematode Steinernema carpocapsae (Rhabditida: Steinernematidae). Journal of Economic Entomology, 87, 366-370. https://doi.org/10.1093/jee/87.2.366

16. Fleming, R., \& Retnakaran, A. (1985). evaluating single treatment data using Abbott's formula with reference to insecticides. Journal of Economic Entomology, 78, 1179-1181. https://doi.org/10.1093/jee/78.6.1179

17. Forst, S., \& Clarke, D. (2002). Bacteria-nematode symbiosis.. In: In Gaugler, R. (Ed.), Entomopathogenic Nematology (pp. 57-77). New York, USA: CABI Publishing

18. Garcia, L. C., Raetano, C. G., \& Leite, L. G. (2008). Application technology for the entomopathogenic nematodes Heterorhabditis indica and Steinernema sp. (Rhabditida: Heterorhabditidae and Steinernematidae) to control Spodoptera frugiperda (Smith) (Lepidoptera: Noctuidae) in corn. Neotrop Entomol, 37(3), 305-311. https://doi.org/10.1590/s1519-566x20080003000

19. Grewal, P. S. (2005). Ehlers RU and Shapiro-llan DI, Nematodes as Biocontrol Agents. CABI Publishing, Wallingford, UK

20. Han, P., Bayram, Y., Shaltiel-Harpaz, L., Sohrabi, F., Saji, A., Esenali, U. T. ... Desneux, N. (2019). Tuta absoluta continues to disperse in Asia: damage, ongoing management and future challenges. J. Pest Sci, 92(4), 1317-1327.

https://doi.org/10.1007/s10340-018-1062-1

Page 12/14 
21. Head, J., Lawrence, A. J., \& Walters, K. F. A. (2004). Efficacy of the entomopathogenic nematode, Steinernema feltiae, against Bemisia tabaci in relation to plant species. J of App/ Entomol, 128, 543-547. https://doi.org/10.1111/j.14390418.2004.00882.x

22. Huang, F., Qureshi, J. A., Meagher, R. L., Reisig, D. D., Head, G. P., Andow, D. A. ... Dangal, V. (2014). Cry1F resistance in fall armyworm Spodoptera frugiperda: single gene versus pyramided Bt maize. PLoS One, 9, 1-10. https://doi.org/10.1371/journal.pone.0112958

23. Kasi, I. K., Singh, M., Waiba, K. M., Monika, S., Waseem, M. A., Archie, D., \& Gilhotra, H. (2021). Bio-efficacy of entomopathogenic nematodes, Steinernema feltiae and Heterorhabditis bacteriophora against the Cabbage butterfly (Pieris brassicae [L.]) under laboratory conditions. Egypt J Biol Pest Control, 31, 125. https://doi.org/10.1186/s41938021-00469-4

24. Kasi, I. K., Waiba, K. W., \& Singh, M. (2021). First report of natural infestation of Ovomermis sinensis (Nematoda: Mermithidae) parasitizing fall armyworm Spodoptera sp. (Lepidoptera: Noctuidae) in Himachal Pradesh, India. Indian Journal of Nematology, 50, 148-149

25. Kaya, H. K., \& Gaugler, R. (1993). Entomopathogenic nematodes. Annual Review of Entomology, 38, 181-206. https://doi.org/10.1146/annurev.en.38.010193.001145

26. Lewis, E. E., Campbell, J. C., Griffn, C., Kaya, H. K., \& Peters, A. (2006). Behavioral ecology of entomopathogenic nematodes. Biolog Control, 38, 66-79. https://doi.org/10.1016/j.biocontrol.2005.11.007

27. Lietti, M. M., Botto, E., \& Alzogaray, R. A. (2005). Insecticide resistance in Argentine populations of Tuta absoluta (Meyrick) (Lepidoptera: Gelechiidae). Neotrop Entomol 34:113-119 (2005). https://doi.org/10.1590/S1519566X2005000100016

28. Malhat, F. M., Haggag, M. N., Loutfy, N. M., Osman, M. A., \& Ahmed, M. T. (2015). Residues of organochlorine and synthetic pyrethroid pesticides in honey, an indicator of ambient environment, a pilot study. Chemosphere, 120, 457461. https://doi.org/10.1016/j.chemosphere.2014.08.032

29. Martens, E. C., \& Goodrich-Blair, H. (2005). The Steinernema carpocapsae intestinal vesicle contains a sub-cellular structure with which Xenorhabdus nematophila associates during colonization initiation. Cellular Microbiology, 7 , 1723-1735. https://doi.org/10.1111/j.1462-5822.2005.00585.x

30. Martens, E. C., Vivas, E. I., Heungens, K., Cowles, C. E., \& Goodrich-Blair, H. (2004). Investigating mutualism between entomopathogenic bacteria and nematodes. Nematology Monographs and Perspectives: Proceedings of the Fourth International Congress on Nematology 2: 447-462

31. Molina, J. O., Hamm, J. J., Gutierrez, R. L., Jaber, L. F. B., Vargas, M. A., \& Ramirez, M. G. (1996). Virulence of six entomopathogenic nematodes (Steinernematidae and Heterorhabditidae) on immature stages of Spodoptera frugiperda (Lepidoptera: Noctuidae). Vedal Rev Int de Cont Bio, 3, 25-29

32. Monnerat, R., Martins, E., Macedo, C., Queiroz, P., Praca, L., Soares, C. M. ... Bravo, A. (2015). Evidence of field-evolved resistance of Spodoptera frugiperda to Bt corn expressing Cry1F in Brazil that is still sensitive to modified Bt toxins. PLoS One, 10, 1-12. https://doi.org/10.1371/journal.pone.0119544

33. Negrisoli, A. S., Garcia, M. S., Barbosa, C. R. C., Bernardi, D., \& da Silva, A. (2010). Efficacy of entomopathogenic nematodes (Nematoda: Rhabditida) and insecticide mixtures to control Spodoptera frugiperda (Smith, 1797) (Lepidoptera: Noctuidae) in corn crops. Crop Protect, 29, 677-683. https://doi.org/10.1016/j.cropro.2010.02.002

34. Nouh, G. H. (2021). Efficacy of the entomopathogenic nematodes isolates against Spodoptera littoralis (Boisduval) and Agrotis ipsilon (Hufnagel) (Lepidoptera: Noctuidae). Egypt J Biol Pest Control, 31(1), 1-5. https://doi.org/10.1186/s41938-021-00374-w

35. Poinar, G. O. (1990). Biology and taxonomy of Steinernematidae and Heterorhabditidae.. In: In Gaugler, R., \& Kaya, H. K. (Eds.), Entomopathogenic nematodes in biological control (pp. 23-58). Boca Raton: CRC Press 
36. Santos-Amaya, O. F., Tavares, C. S., Monteiro, H. M., Teixeira, T. P. M., Guedes, R. N. C., Alves, A. P., \& Pereira, E. J. G. (2016). Genetics basis of Cry1F resistance in two Brazilian populations of fall armyworm. Crop Protect, 81, 154-162. https://doi.org/10.1016/j.cropro.2015.12.014

37. Shapiro-llan, D., Han, R., \& Qiu, X. (2014). Production of entomopathogenic nematodes.. In: In Morales-Ramos, J., Rojas, G., \& Shapiro-llan, D. I. (Eds.), Mass Production of Beneficial Organisms: Invertebrates and Entomopathogens (pp. 321-356). San Diego, California, USA: Academic Press, Elsevier Inc.

38. Sharma, P. L., \& Gavkare, O. (2017). new distributional record of invasive pest Tuta absoluta (Meyrick) in North-Western Himalayan region of India. Nat Acad Sci Lett, 40, 217-220. https://doi.org/10.1007/s40009-016-0526-1.

39. Sicard, M., Brugirard-Ricaud, K., Pages, S., Lanois, A., Boemare, N. E., Brehelin, M., \& Givaudan, A. (2004). Stages of infection during the tripartite interaction between Xenorhabdus nematophila, its nematode vector, and insect hosts. Appli and Environ Microb, 70, 6473-6480. https://doi.org/10.1128/AEM.70.11.6473-6480.2004

40. Silva, C. P., Waterfield, N. R., Daborn, P. J., Dean, P., Chilver, T., Au, C. P. Y. ... Ffrench-Constant, R. H. (2002). Bacterial infection of a model insect: Photorhabdus luminescens and Manduca sexta. Cell Microbiolo 4: 329-339 (2002). https://doi.org/10.1046/j.1462-5822.2002.00194.x

41. Sridhar, V., Chakaravarthy, A. K., Asokan, R., Vinesh, L. S., Rebijith, K. B., \& Vennila, S. (2014). New record of the invasive South American tomato leafminer, Tuta absoluta (Meyrick) (Lepidoptera: Gelechiidae) in India. Pest Manag. Hortic. Ecosyst, 20, 148-154

42. Viteri, D., Linares, A., \& Flores, L. (2018). Use of the entomopathogenic nematode Steinernema carpocapsae in combination with low-toxicity insecticides to control fall armyworm (Lepidoptera: Noctuidae) larvae. Fla Entomol ss, 101(2), 327-329. https://doi.org/10.1653/024.101.0228

43. Waiba, K. M., Sharma, P., Kumar, K. I., \& Chauhan, S. (2021). Studies of Genetic Variability of Tomato (Solanum lycopersicum L.) Hybrids under Protected Environment. International Journal of Bio-resource and Stress Management, 12, 264-270. https://doi.org/10.23910/1.2021.2211.

44. Williams, E. C., \& Walters, K. F. A. (2000). Foliar application of the entomopathogenic nematode Steinernema feltiae against leaf miners on vegetables. Bio Sci and Techn, 10, 61-70. https://doi.org/10.1080/09583150029396

45. Yu, S. J. (1991). Insecticide resistance in the fall armyworm, Spodoptera frugiperda (J. E. Pest Bioche and Physiol, 39 , 84-91. https://doi.org/10.1016/0048-3575(91)90216-9Smith

46. Zhu, Y. C., Blanco, C. A., Portilla, M., Adamczyk, J., Luttrell, R., \& Huang, F. (2015). Evidence of multiple/cross resistance to Bt and organophosphate insecticides in Puerto Rico population of the fall armyworm, Spodoptera frugiperda. Pestic Biochem Phys, 122, 15-21. https://doi.org/10.1016/j.pestbp.2015.01.007

47. Bhairavi, K. S., Bhattacharyya, B., Devi, G., Bhagawati, S., Das, P. P. G., Devi, E. B., \& Manpoong, N. S. (2021). Evaluation of two native entomopathogenic nematodes against Odontotermes obesus (Rambur) (Isoptera: Termitidae) and Agrotis ipsilon (Hufnagel) (Lepidoptera: Noctuidae). Egypt J Biol Pest Control, 31, 111. https://doi.org/10.1186/s41938-021-00457-8

48. Alforja, S. I. R., Rico, P. M. B., Caoili, B. L., \& Latina, A. R. (2021). Two Philippine Photorhabdus luminescens strains inhibit the in vitro growth of Lasiodiplodia theobromae, Fusarium oxysporum f. sp. lycopersici, and Colletotrichum spp. Egypt J Biol Pest Control, 31, 108. https://doi.org/10.1186/s41938-021-00454-x 